\title{
SMARTPHONE MEDIA BERKARYA SENI VISUAL MASA KINI
}

\author{
Rony Siswo Setiaji \\ Pendidikan Seni Rupa dan Kriya, Universitas Negeri Yogyakarta \\ Email: ronysiswo@uny.ac.id
}

\begin{abstract}
Abstrak
Dunia telah memasuki Era Revolusi Industri 4.0. Era dimana terjadi percepatan teknologi dan digitalisasi dalam berbagai bidang. Informasi, komunikasi, interaksi, transaksi dan edukasi dapat dilakukan hanya dalam genggaman layar smartphone. Begitu pula dalam menciptakan sebuah karya seni dan desain dapat memanfaatkan teknologi smartphone. Berdasarkan studi pendahulan yang dilakukan peneliti yaitu sekitar $80 \%$ mahasiswa seni rupa dan desain tidak menggunakan teknologi smartphone untuk berkarya seni. $60 \%$ dari mereka tidak mengenal aplikasi smartphone yang dapat dimanfaatkan untuk berkarya seni. Tulisan ini bertujuan membahas peran penggunaan teknologi khususnya smartphone dalam kegiatan berkarya seni dan desain. Berikutnya, juga membahas berbagai aplikasi untuk berkarya seni kreatif seperti filpaclip, medibangpaint, procreate, sketchbook, artflow, infinite design serta adobe ilustrator. Terakhir, tulisan ini membahas tentang bisnis karya seni dan desain online melalui berbagai alamat website yang dapat diakses menggunakan layar smartphone. Diharapkan mahasiswa seni rupa dan desain dapat memanfaatkan perkembangan teknologi tidak hanya untuk kepentingan pribadi semata, namun juga kegiatan berkarya seni kreatif serta dapat menghasilkan income.
\end{abstract}

Kata Kunci: Seni, Desain, Teknologi, Smartphone, Digital

SMARTPHPONE, A MEDIA FOR CREATING VISUAL ART \& DESIGN NOWADAYS

\begin{abstract}
The world has entered the Industrial Revolution Era 4.0. The era where technology accelerated and digitalized in various aspects. Information, communication, interaction, transactions and education are done via a smartphone. In creating a work of art and design can be done with smartphone technology. However, based on the preliminary study conducted by researcher, around $80 \%$ of art and design students do not use smartphone technology to create art. $60 \%$ of them are not familiar with smartphone applications that can be used to create art. The objective of this paper is to discuss the role of the use of technology, especially smartphones in the work of art and design. Next, discuss various applications to create creative arts such as filpaclip, medibang paint, procreate, sketchbook, artflow, infinite design and adobe illustrator. Finally, this paper discusses the online art and design business through various website addresses that can be accessed using a smartphone screen. Therefore, it is expected that fine arts and design students can take advantage of technological developments not only for personal gain, but also for creative arts activities and can generate income.
\end{abstract}

Keywords: Arts, Design, Technology, Smartphone, Digital 


\section{PENDAHULUAN}

Era Revolusi Industri 4.0 adalah era dimana terjadi percepatan teknologi dan digitalisasi dalam berbagai bidang, era yang tidak memiliki batasan jarak, ruang dan waktu. Revolusi industri 4.0 merupakan suatu era kemajuan teknologi terkini dimana internet dan teknologi berfungsi dalam mengintegrasikan objek, manusia, mesin yang cerdas, lini produksi dan proses yang membentuk sesuatu yang baru, cerdas, terhubung dan gesit (Schumacer, 2016).

Kehadiran revolusi industri 4.0 memiliki beberapa tujuan seperti mempersingkat waktu dan siklus inovasi, membuat lebih banyak produk yang lebih rumit dan canggih, memperbesar volume data, meningkatkan fleksibelitas dalam produksi masal dan produktifitas yang lebih tinggi serta mendorong efisiensi energi dan meningkatkan sumber daya (Nasution, 2018). Adanya revolusi industri dan semakin berkembangnya hardware, software serta koneksi internet, masyarakat di dunia telah mengubah pola pikir dan gaya hidupnya dari kegiatan fisik (nyata) yang dialihkan menjadi kegiatan dalam dunia maya (internet).

Informasiyang dahulumembutuhkan waktu untuk sampai ke penerima informasi kini dalam sekejap dapat diakses melalui berbagai media digital. Komunikasi yang dahulu hanya sebatas berkirim surat, kini kapanpun dan dimanapun kita bisa berkomunikasi baik melalui email, chating, bahkan video call. Interaksi juga dapat dilakukan oleh siapa saja dari berbagai belahan dunia manapun melalui media sosial seperti instagram, twitter dan facebook. Transaksi tidak memerlukan pertemuan tatap muka antara penjual dan pembeli, pembayaran langsung di toko, atau pergi ke ATM hanya sekedar mengambil uang tunai. Transaski saat ini bisa menggunakan layanan M-banking, Dana Online dan E-commerce. Kegiatan belajarmengajar dalam dunia pendidikan, yang biasa dilakukan di dalam kelas atau bertatap muka secara langsung antara pengajar dan peserta didik, kini dapat dilakukan secara online dan jarak jauh dengan memanfaatkan E-learning (Pratama, 2015).
Informasi, komunikasi, interaksi, transaksi dan edukasi dapat dilakukan hanya dalam genggaman layar smartphone. Begitu pula dalam menciptakan sebuah karya seni dan desain dapat memanfaatkan teknologi smartphone. Meskipun secara umum smartphone berfungsi sebagai alat komunikasi. Kini dengan perkembangannya, smartphone dapat digunakan sebagai media dalam menghasilkan karya seni dan desain melalui aplikasi yang terdapat di dalamnya. Karya seni dan desain yang diciptakan melalui perangkat komputer atau perangkat elektronik lainnya termasuk smartphone dinamakan digital art. Hal ini sejalan dengan pendapat Marcos (2019) bahwa digital art adalah karya seni dan desain yang mengekplorasi komputer (alat teknologi, kode digital dan konten informasi) sebagai alat dan bahan dalam menciptakan sebuah karya seni dan desain. Melalui teknologi smartphone kita bisa menciptakan karya seni dan desain yaitu logo, poster, gambar, ilustrasi, fotografi, videografi dan animasi. Terdapat beberapa software atauaplikasiyang dapatmempermudah kita dalam berkarya seperti filpaclip, medibang paint, procreate, sketchbook, artflow, infinite design serta adobe ilustrator. Dengan adanya beberapa aplikasi tersebut, berkarya seni dan desain menjadi lebih mudah, lebih cepat dan dapat dilakukan dimana saja.

Berdasarkan studi pendahuluan yang dilakukan oleh peneliti sebanyak $80 \%$ mahasiswa seni rupa dan desain tidak pernah menggunakan smartphone dalam menciptakan karya seni dan desain. Sekitar $60 \%$ mahasiswa tidak mengenal aplikasi smartphone yang dapat digunakan dalam menciptakan karya seni dan desain. $55 \%$ mahasiswa tidak pernah menjual atau mempromosikan karya seni dan desain melalui website jual beli karya seni dan desain secara online. Berdasarkan hal itu tulisan ini akan membahas peran teknologi smartphone dalam menciptakan karya seni dan desain. Tulisan ini juga akan membahas berbagai aplikasi yang dapat dimanfaatkan dalam menciptakan karya seni dan desain meliputi filpaclip, medibangpaint dan procreate. Pembahasan selanjutnya akan memberikan 
penjelasan tentang bisnis karya seni dan desain melalui berbagai website yang dapat diakses menggunakan smartphone meliputi tees.co.id dan zazzla.com. Melalui tulisan ini, dengan demikian, mahasiswa seni rupa dan desain dapat memanfaatkan perkembangan teknologi smartphone dalam mencipatakan karya seni dan desain secara kreatif dan mendapatkan income tambahan dari menjual karya seni dan desain yang dihasilkannya.

\section{PEMBAHASAN}

1. Peran teknologi smartphone dalam kegiatan berkarya seni dan desain

Perkembangan teknologi informasi dan komunikasi sungguh sangat pesat, termasuk perkembangan telepon genggam atau handphone. Dahulu handphone hanya dapat digunakan sebagai alat komunikasi seperti telepon dan berkirim pesan singkat. Kini handphone sudah berkembang menjadi alat yang lebih cangih dan pintar yang biasa kita kenal dengan istilah smartphone.

Telpon pintar atau smartphone telah dilengkapi kemampuan seperti komputer. Smartphone memiliki beberapa fitur canggih seperti video call, kamera dengan resolusi tinggi, browser dan aplikasi penunjang lainnya yang terus berkembang hingga saat ini. Sejalan dengan pendapat Rouse dalam teachtarget.com (2018) perbedaan antara ponsel biasa dengan smartphone yaitu smartphone memiliki fitur yang lebih canggih termasuk web browsing, aplikasi software dan mobile operasi sistem. Beberapa fitur utama yang harus dimiliki oleh smartphone meliputi koneksi internet, browser, kemampuan menyinkronkan lebih dari satu akun email ke perangkat, memiliki memori internal, wifi, terhubung dengan perangkat lain seperti komputer/ laptop, touchscreen, digital camera, games, GPS sertamemiliki kemampuan dalam mengunduh aplikasi dan menjalankanya secara mandiri. Salah satu fitur penting dari smartphone adalah terhubung dengan appstore. Appstore merupakan tempat dimana pengguna dapat mengunduh berbagai aplikasi perangkat lunak. Appsstore menawarkan ribuan aplikasi selular untuk produktivitas, permainan video games, membuat dokumen, media sosial termasuk aplikasi dalam menciptakan karya seni dan desain.

Menciptakan karya seni dan desain saat ini lebih mudah karena dapat dilakukan dimana saja dan kapan saja dengan menggunakan aplikasi dalam genggaman layar smartphone. Berbagai karya seni yang dapat dihasilkan dengan menggunakan smartphone yaitu logo, poster, gambar, ilustrasi, fotografi, videografi dan animasi. Aplikasi smartphone yang tersedia untuk menunjang kegiatan berkarya seni meliputi filpaclip, medibang paint, procreate, sketchbook, artflow, infinite design serta adobe ilustrator. Tidak bisa dipungkiri saat ini smartphone tengah menjadi media yang banyak digunakan oleh creator dan seniman di dunia dalam menciptakan karya seni dan desain. Berkarya dengan smartphone dapat menggantikan fungsi kanvas dan buku skesta serta lebih murah hanya dengan mengunduh aplikasi di appstore. Seorang seniman digital art yang masih pemula atau seniman yang telah berpengalaman, dapat dengan mudah menemukan aplikasi yang ramah terhadap pengguna sesuai kemampuan dan membuat keadaan menyenangkan untuk berkarya seni selama berjam-jam (Sawyer, 2019).

Smartphone tidak hanya untuk menciptakan karya seni dan desain, tetapi juga berperan dalam menyebarluaskan hasil dan proses pembuatan karya seni dan desain baik melalui aplikasi atau website. Rahman (2016) menjelaskan aplikasi dalam smartphone seperti misalnya instagram juga digunakan sebagai galeri gengaman dan menjual karya seni. Hal ini sejalan dengan pendapat Setiaji (2017) instagram menjadi ruang kreatif dalam mengunggah karya seni dan desain terbaik, instagram juga sebagai media dalam berbisnis karya seni dan desain, serta sebagai sumber inspirasi dan apresiasi karya seni dan desain.

\section{Aplikasi smartphone dalam kegiatan berkarya seni dan desain}

Smartphone saat ini tidak hanya sebagai media komunikasi namun juga media dalam berkaryasenidandesain. Denganmemanfaatkan 
aplikasi yang tersedia di appstore kita dapat menciptakan berbagai karya seni dan desain meliputi fotografi, videografi, ilustrasi, digital painting dan animasi. Aplikasi yang dapat menunjang kegiatan berkarya seni dan desain yaitu filpaclip, medibang paint, procreate, sketchbook, artflow, infinite design serta adobe ilustrator. Namun pada pembahasan dalam tulisan ini, penulis hanya terfokus pada tiga aplikasi yaitu medibang paint, procreate dan flipaclip.

Penggunaan aplikasi smartphone dalam kegiatan berkarya seni dan desain akan lebih mudah jika menggunakan alat penunjang seperti stylus pen. Stylus pen dapat didapatkan secara terpisah atau bersamaan dengan jenis atau merk smartphone tertentu. Saat ini stylus pen dapat kita peroleh dengan harga sangat terjangkau. Di pasaran juga telah beredar berbagai jenis, model dan kegunaan stylus pen dengan kemampuan khusus untuk membuat karya seni dan desain. Penulis merekomendasikan produk stylus pen dengan merk adonit. Adonit merupakan stylus pen yang dapat digunakan dalam smartphone berbasis andorid dan iOS. Pengguna dapat memilih berbagai type produk adonit sesuai dengan kemampuan dan kegunaan yang diingkan.

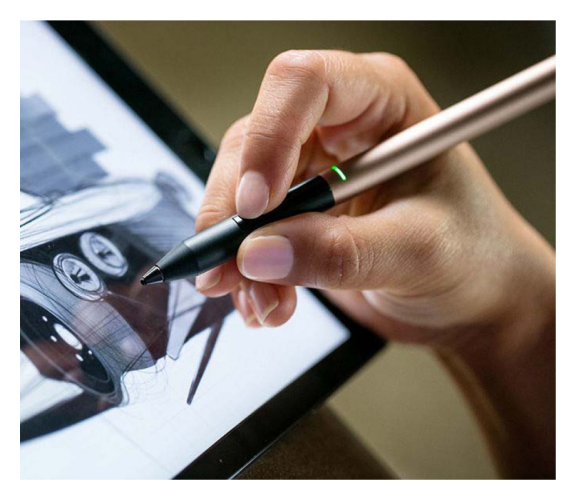

Gambar 1. Gambar Stylus Pen Alat Penunjang Desain Smartphone

Sumber: https://www.adonit.net/ Diunduh pada tanggal 9 Sepetember 2019

a. Berkarya seni dan desain melalui medibang paint

Medibang paint adalah aplikasi atau software yang dapat membantu dalam membuat karya seni dan desain khususnya ilustrasi, digital painting bahkan membuat komik. Medibang paint dapat didownload dan diinstal pada smartphone secara gratis melalui appstore. Medibang paint tersedia pula dalam perangkat Windows, Mac OS X, Android, dan iOS. Medibang paint menggunakan penyimpanan could yang memungkinkan pengguna dalam mengelola, mencadangkan dan berbagi hasil karya seni dan desain dengan aman.

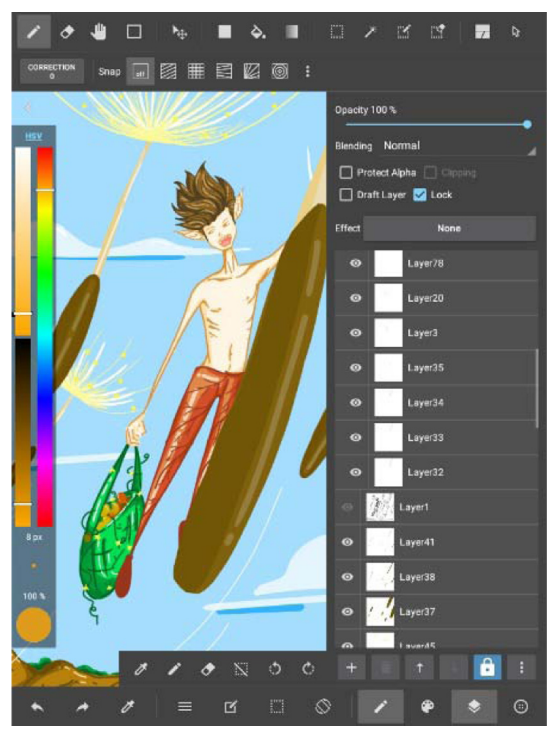

Gambar 2. Tampilan gambar kerja aplikasi medibang paint Sumber: dokumentasi pribadi

Pengguna pada aplikasi medibang paint, mendapat berbagai fasilitas tool untuk menunjang pembuatan karya seni dan desain. Medibang paint dilengkapi dengan 60 kuas seperti pen, pencil, G-pen, Watercolor, Blur dan Smudge. Aplikasi ini memungkinkan pengguna dalam menggunakan dua mode warna yaitu PAL dan HVS. Sepintas tampilan gambar kerja aplikasi medibang paint tidak jauh berbeda dengan tampilan adobe photoshop. Aplikasi ini juga dapat menambah, memindah dan menghapus layer gambar kerja. Sawyer (2019) menambahkan aplikasi medibang paint memiliki sedikit kompleksitas dalam tampilan dan fiturnya sehingga memungkinkan pengguna baru akan mengalami kesulitan, namun bagi yang berpengalaman aplikasi ini sangat menyenangkan. 


\section{b. Berkarya seni dan desain melalui procreate}

Procreate adalah aplikasi yang hanya tersedia di appstore pada perangkat iOS. Procreate didesain khusus untuk profesional digital artis. Aplikasi ini memiliki ratusan variasi kuas meliputi skteching, ingking, calligraphy bahkan airbrushing. Aplikasi procreate menyediakan berbagai pilihan bagi pengguna dalam membuat, menyesuaikan, memodifikasi dan mengimpor kuas.

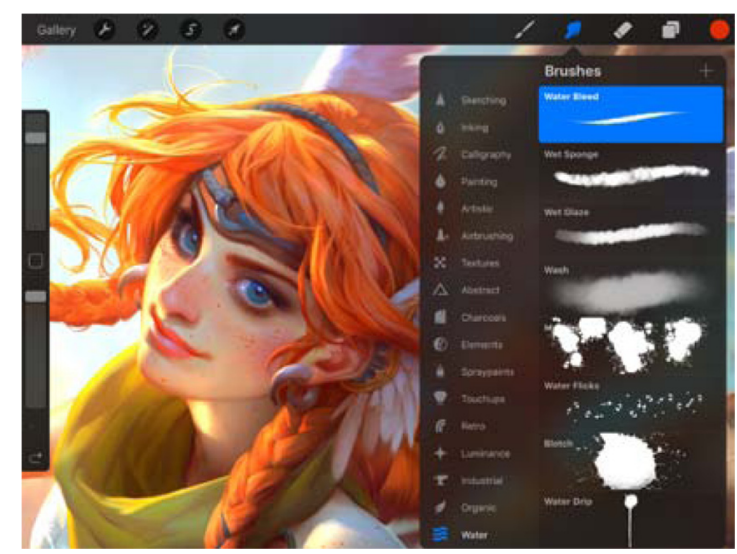

Gambar 2. Tampilan gambar kerja aplikasi procreate

Sumber: https://www.stuff.tv/app-reviews/procreate/review diunduh pada tanggal 9 September 2019

Aplikasi procreate memiliki fitur yang jarang dimiliki aplikasi lainnya yaitu selection tool dan transform tool. Selection tool berfungsi memindahkan atau menggeser objek yang telah kita seleksi sesuai posisi yang kita inginkan. Tool ini juga berfungsi menyeleksi objek agar dapat kita edit tanpa harus keluar dari zona seleksi. Transform tool berfungsi memperbesar dan memperkecil objek. Aplikasi procreate memberi semua yang dibutuhkan oleh seniman digital art dalam membuat sketsa kreatif, ekspresif, lukisan dan ilustrasi yang indah. Apabila ingin melihat hasil karya yang dihasilkan melalui aplikasi procreate, kita dapat membuka dan melihat akun instagram @ procreate.

\section{c. Membuat animasi melalui filpaclip}

Filpaclip adalah aplikasi atau software yang dapat membantu animator dalam membuat karya animasi atau gambar bergerak. Flipaclip merupakan aplikasi yang dapat diunduh dan diinstal secara gratis melalui appstore. Aplikasi ini memungkinkan kita dalam membuat klip dan bekerja dengan prinsip frame-by-frame. Beberapa fitur yang disedikan dalam aplikasi ini meliputi alat menggambar seperti kuas, penghapus, lasso tool, ink tool dan rurel tool.

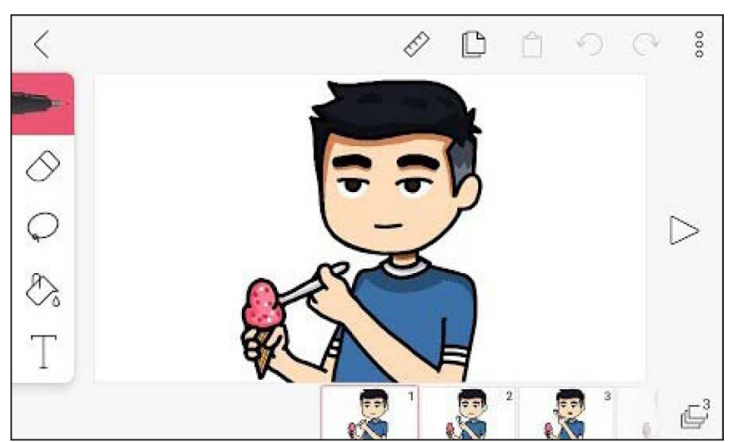

Gambar 3. Tampilan gambar kerja aplikasi flipaclip

Sumber: https://youtu.be/vUAWydGlYqE diunduh pada tanggal 10 September 2019

Proses pembuatan animasi menggunakan aplikasi ini cukup mudah. Pertama kita harus membuat proyek baru dengan menekan tombol $(+)$, kemudian mengatur nama proyek, ukuran kanvas, dan memilih frame per detik. Kita dapat mengatur ukuran kanvas sesuai kebutuhan meliputi youtube (1080p/ 720p), instagram (16:9/ 1:1) serta ukuran lainya seperti tiktok (1080p/ 720p) dan tumblr (16:9/ 4:3). Kita juga dapat mengatur Frame per second (fps) mulai dari 1 fps hingga 30 fps. Kedua adalah tahap membuat animasi pada kanvas menggunakan peralatan gambar yang tersedia. Tahap ketiga mengatur durasi, jumlah kanvas serta menambahkan backsound dari audio atau rekaman suara. Terakhir, kita dapat memutar animasi dan melihat hasil karya yang telah kita buat. Apabila kita ingin melihat hasil karya animasi yang dihasilkan melalui aplikasi flipaclip, kita dapat membuka dan melihat akun instagram@flipaclip. 


\section{d. Bisnis karya seni dan desain melalui website.}

Perkembangan teknologi saat ini memungkinan seseorang dapat melakukan berbagai hal dalam genggaman smartphone, termasuk menjual produk dengan mudah, cepat dan menghasilkan keuntungan. Seorang desainer atau seniman saat ini dapat menjual karya seni dan desain miliknya melalui market place secara online melalui website jual-beli online. Karya seni dan desain yang dihasilkan tidak hanya bisa dinikmati keindahanya namun juga menghasilkan penghasilan tambahan bagi penciptanya. Beberapa website yang bisa dijadikan alternatif para desainer atau creator yaitu tees.co.id, zazzle.com, sribu. com, designbyhumans.com, displate.com, spreadshirt.com, cafepress.com, dan redbubble. com. Dalam tulisan ini penulis hanya berfokus pada dua market place yaitu tees.co.id dan zazzla.com. Kedua market place ini memberi kemudahan dan memiliki banyak jenis produk bagi creator atau desainer untuk membuat dan menjual karya desainnya.

\section{Menjual karya desain melalui website tees.co.id}

Wesbite tees.co.idadalah market place yang menyediakan jasa jual-beli beragam produk desain. Desainer dapat menjual hasil karyanya yang telah didesain pada produk yang tersedia pada website ini. Produk yang disediakan pada website tees.co.id meliputi kaos, jaket, tas, drinkware, stationary, headware, home decor dan produk lainnya. Pengguna dapat membeli, mendesain dan menjual produk ciptaannya. Pengguna juga dapat membuat toko online yang berisikan produk-produk karya sendiri. Tees.co.id telah menghasilkan sekitar 400.000 karya desain yang berasal dari 50.000 kreator. Tugas mitra bisnis tees.co.id hanya bertugas membuat dan menciptakan karya desain, sedangkan tugas produksi, jumlah persediaan produk, proses pengiriman, pembayaran dan barang sampai ke tangan pelanggan adalah tanggung jawab tees.co.id (Suryanto, 2019).

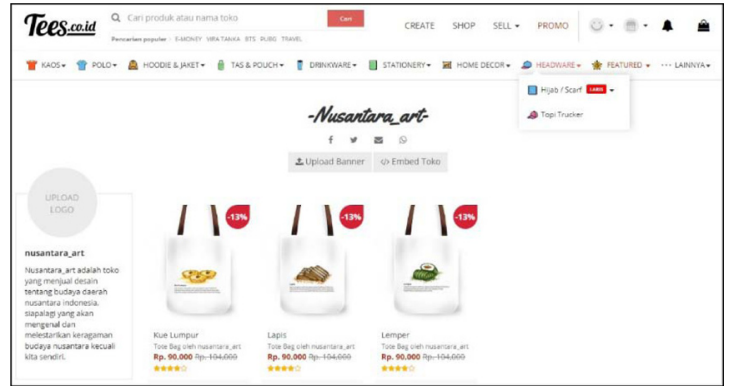

Gambar 4. Tampilan Website tees.co.id

Sumber: https://tees.co.id/products/search/nusantara_art/ model?keyword=nusantara art diunduh pada tanggal 10 September 2019

\section{Menjual karya desain melalui zazzle. com}

Zazzle.com merupakan market place atau pasar online dimana desainer dapat membuat dan menjual produknya sendiri. Desainer hanya bertugas mendesain produk, sedangkan proses penjualan, marketing, pelayanan pelanggan menjadi tanggung jawab pihak zazzle.com. Dengan mendesain dan menjual produk desain melalui zazzle.com kita akan mendapatkan keutungan apabila produk terjual. Desainer juga dapat menentukan harga produk buatan sendiri dan menentukan persentasi royalti yang akan diperoleh. Produk yang dapat didesain dan dijual oleh desainer meliputi kategori kartu dan undangan, kaos dan aksesories, rumah, eletronik, kantor, bayi dan anak, seni, pernikahan dan hadiah.

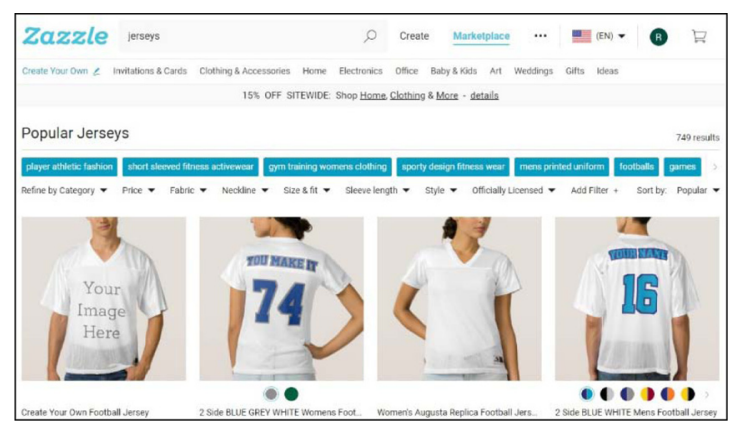

Gambar 5. Tampilan Website zazzle.com Sumber: https://www.zazzle.com/c/jerseys diunduh pada tanggal 10 September 2019

\section{KESIMPULAN}

Perkembangan teknologi informasi dan komunikasi telah berkembang sangat 
pesat, begitupula dengan perkembangan telepon genggam atau handphone. Dahulu handphone memiliki kemampuan sebatas berkirim pesan dan telepon. Namun kini alat komunikasi tersebut memiliki kemampuaan lebih cerdas dan lebih canggih dengan segala fitur di dalamnya. Perkembangan teknologi smartphone tidak hanya digunakan sebagai alat komunikasi semata, namun juga dapat dimanfaatkan dalam kegiatan berkarya seni dan desain. Karya seni dan desain yang dapat diciptakan melalui media smartphone meliputi desain logo, ilustrasi, komik, digital painting, dan animasi. Berbagai aplikasi yang dapat menunjang kegiatan berkarya seni digital yaitu filpaclip, medibangpaint, dan procreate, Selain bermanfaat dalam menciptakan karya seni dan desain, smartphone jaga dapat menghasilkan keuntungan bagi desainer dan creator. Desainer dan creator dapat menjual hasil karya seni dan desain melalui market place seperti tees. co.id dan zazzla.com. Melalui pembahasan dalam tulisan ini diharapkan mahasiswa seni dan desain memiliki pengetahuan, referensi dan mampu memanfaatkan perkembangan teknologi smartphone dalam kegiatan berkarya seni dan desain serta menghasilkan keuntungan tambahan dengan menjual karya seni dan desain yang telah diciptakannya.

\section{DAFTAR PUSTAKA}

Marcos, Adérito Fernandes. 2009. The Creation Process in Digital Art. New York: Handbook of Multimedia for Digital Entertainment and Arts, Book, Chapter 27. pp.601-615.
Nasution, Arman Hakim. 2018. Inovasi. Yogyakarta: ANDI.

Pratama, I Putu Agus Eka. 2015. E-commerce, E-business, Mobile Commerce. Bandung: Informatika Bandung.

Rahman, Arham. 2016. Lini Masa. Perhial Teknologi dan Seni. Yogayakarta: Mata Jendela/ Volume XI nomor4/ 2016.

Rouse, Margaret. 2018. Definition Smartphone. Diaksespadatanggal9September2019pada halaman https://searchmobilecomputing. techtarget.com/definition/smartphone

Sawyer, McKella. 2019. Best Drawing \& Painting Apps For Mobile Artists (iOS + Android). Diakses pada tanggal 9 September 2019 pada halaman https:// conceptartempire.com/best-drawingpainting-apps/

Schumacher, Andreas., Selim Erol., Wilfried Sihn. 2016. A Maturity Model for Assessing Industry 4.0 Readiness and Maturity of Manufacturing Enterprises. Elsevier B.V. Procedia CIRP 52. pp. 161-166.

Setiaji, Rony Siswo. 2017. Karya Seni Dalam Genggaman: Ruang Kreatif, Sumber Inspirasi dan Apresiasi. In: Seminar Nasional Seni, Budaya, dan Desain (SEDESA 2017), 3 Oktober 2017, Jurusan Seni dan Desain, Fakultas Sastra, Universitas Negeri Malang.

Suryanto, Veni (2019). Marketplace Tees.co.id Membidik Pasar Desain Custom. Diakses pada tanggal 10 Sepetmber 2019 pada laman https://peluangusaha.kontan.co.id/ news/marketplace-teescoid-membidikpasar-desain-custom 